\title{
Offspring of patients with tracheo-oesophageal fistula
}

\author{
JOAN WARREN, KATHLEEN EVANS, AND C. O. CARTER \\ From the MRC Clinical Genetics Unit, Institute of Child Health, London WCIN IEH
}

SUMMARY One previous study has shown that the proportion affected of sibs of index patients with tracheo-oesophageal fistula is low. The survivors of the first successful operations for tracheo $\overrightarrow{\vec{w}}$ oesophageal fistula are now reaching adult life, thus making possible a preliminary estimate of the proportion affected of children of index patients. From the records of two London hospitals a listo of 99 consecutive patients was compiled; they were alive after operation and not known to have died since. Of these, 7 were living abroad, 4 were not willing to co-operate, and 9 (alive when laster seen at hospital and probably still living) were not traced. The families of the remaining 79 were $\sum_{\infty}^{\infty}$ visited.

Of the 79,15 were found to have had children; 13 of these had the common type $3 \mathrm{~b}$ oesophagea $\stackrel{\circ}{\mathrm{P}}$ atresia (with a fistula between the trachea or main bronchus and lower segment of the oesophagus) $\vec{b}$ and the other two probably had the same lesion. These 15 patients have so far had 28 children and? only one had tracheo-oesophageal fistula (again type $3 \mathrm{~b}$ ).

The 79 patients had had 130 sibs, of whom one had oesophageal atresia (without fistula), 3 had neural tube defects, and 2 had pyloric stenosis.

The series, though small, already indicates that the proportion affected of children of patients is too small for the disorder in the parents to have been caused by a dominant mutation. For genetic counselling it is, perhaps, reasonable for the present to assume that the risk to children is similar tos the risk for sibs and may not be more than $1 \%$.

The development and separation of the trachea from the oesophagus (Gray and Skandalakis, 1972) is a complex process, which provides ample opportunity for error leading to an embryologically related group of malformations. The primary failure is that the lateral ridges, which project into the foregut below the pharynx, and separate it into a ventral oesophagus and dorsal trachea, fail to fuse for a short length. The consequent malformations include: failure of separation of trachea and oesophagus, partial or complete absence of trachea or oesophagus, oesophageal atresia, oesophageal atresia with tracheal fistula, and tracheo-oesophageal fistula without oesophageal atresia. Much the commonest (75 to $80 \%$ ) of these malformations is oesophageal atresia with a fistula between the lower portion of the oesophagus and the trachea or a main bronchus (type 3b; Vogt, 1929). In these cases, the portion of foregut where the lateral ridges have failed to fuse has become entirely differentiated into trachea, with a corresponding absence of a segment of oesophagus, and a fistula from the lower portion of the oesophagus to the trachea or main bronchus.

The birth frequency of the group of conditions is Received for publication 5 February 1979 about 1 in 3000 live births. The Birmingham Registry (Leck et al., 1968) showed a frequency ats 0 to 2 weeks of 1 in 3190 total births, while the Liverpool Registry (Cudmore, 1978) showed frequency of 1 in 3030 live births. About $50 \%$ of cases have a major associated malformation (David and O'Callaghan, 1975).

Patients successfully treated for tracheo-oeso? phageal fistula are now reaching young adult life and therefore there is a need for an estimate of the risk of similar malformation in their childreng There are two reports (Engle et al., 1970; Dennis et al., 1973) of tracheo-oesophageal fistula in paren (mother in each case) and child. There are, however no reports yet of the children of a consecutive series of surviving patients. We report such a study of index patients treated at two London hospitals a generation ago. The index patient of Dennis et al. (1973) was a member of this series.

\section{Method}

The source of patients was those treated operativel $\vec{\Phi}$ in infancy (excluding two with Down's syndrome\$ who have survived operation. These patients aro 
likely to be relatively homogeneous, since cases which were the result of chromosome anomalies and those with major associated malformations would have tended to die young. There were 79 patients treated at The Hospital for Sick Children and 20 treated at the Hammersmith Hospital between 1947 and 1959 who were not known to have died during follow-up. Of the total 99, we were able to trace and interview the families of 79. Those not seen included 7 living overseas, 9 not traced (though probably still alive), and 4 not willing to be interviewed. For the remaining 79, a full family history was taken and medical records obtained for any of the patients' children, sibs, nephews, or nieces who died in infancy or had a possible history of tracheooesophageal atresia or other malformation.

\section{Results}

\section{CHILDREN}

At present 15 patients have reproduced and between them have a total of 28 children. In 13 of the index patients the malformation was the common type $3 \mathrm{~b}$ (with oesophageal atresia and a fistula between the trachea and lower segment of the oesophagus; Vogt, 1929). In 2 index patients the type of malformation is not known. Of all the 28 children only one, a son of index patient 49 , had tracheo-oesophageal fistula. The children are listed in Table 1 , where the types of tracheo-oesophageal fistula and of other associated malformation in index patient and child

Table 1 Offspring of survivors of tracheo-oesophageal fistula indicating those affected $(A)$ as well as other malformations in survivors and offspring

\begin{tabular}{|c|c|c|c|c|c|c|c|}
\hline & \multirow[t]{2}{*}{$N o$} & \multirow[t]{2}{*}{$H p$} & \multirow[t]{2}{*}{$D O B$} & \multirow{2}{*}{$\begin{array}{l}\text { Type } \\
\text { TOF }\end{array}$} & \multirow{2}{*}{$\begin{array}{l}\text { Associated } \\
\text { anomalies }\end{array}$} & \multicolumn{2}{|c|}{ Children } \\
\hline & & & & & & Male & Female \\
\hline \multirow{2}{*}{$\begin{array}{l}\text { Male } \\
\text { index } \\
\text { patients }\end{array}$} & 1 & $\mathbf{H}$ & 248 & NK & $\begin{array}{c}\text { Pulmonary } \\
\text { stenosis }\end{array}$ & 0 & 3 \\
\hline & $\begin{array}{r}5 \\
7 \\
8 \\
12\end{array}$ & $\begin{array}{l}\mathbf{G} \\
\mathbf{G} \\
\mathbf{G} \\
\mathbf{G}\end{array}$ & $\begin{array}{ll}5 & 51 \\
2 & 52 \\
5 & 52 \\
3 & 53\end{array}$ & $\begin{array}{l}3 \mathrm{~b} \\
3 \mathrm{~b} \\
3 \mathrm{~b} \\
3 \mathrm{~b}\end{array}$ & $\begin{array}{l}\text { None } \\
\text { None } \\
\text { None } \\
\text { None }\end{array}$ & $\begin{array}{l}1 \\
1 \\
1 \\
1\end{array}$ & $\begin{array}{l}1 \\
0 \\
0 \\
1\end{array}$ \\
\hline \multirow{4}{*}{$\begin{array}{l}\text { Female } \\
\text { index } \\
\text { patients }\end{array}$} & 49 & $\mathbf{G}$ & 948 & $3 b$ & None & $\begin{array}{l}2(\mathrm{~A} \\
3 \mathrm{~b})\end{array}$ & 1 \\
\hline & $\begin{array}{l}50 \\
54 \\
55 \\
56\end{array}$ & $\begin{array}{l}\mathbf{G} \\
\mathbf{H} \\
\mathbf{G} \\
\mathbf{G}\end{array}$ & $\begin{array}{rl}10 & 48 \\
7 & 51 \\
3 & 52 \\
5 & 52\end{array}$ & $\begin{array}{l}3 \mathbf{b} \\
\text { NK } \\
3 \mathbf{b} \\
3 \mathrm{~b}\end{array}$ & $\begin{array}{l}\text { None } \\
\text { None } \\
\text { None } \\
\text { None }\end{array}$ & $\begin{array}{l}0 \\
1 \\
1 \\
1 \\
\text { (Hypo } \\
\text { spadia }\end{array}$ & $\begin{array}{l}1 \\
1 \\
0 \\
1 \\
- \\
\text { as) }\end{array}$ \\
\hline & $\begin{array}{l}58 \\
61 \\
66\end{array}$ & $\begin{array}{l}\mathbf{G} \\
\mathbf{H} \\
\mathbf{H}\end{array}$ & $\begin{array}{ll}8 & 52 \\
6 & 54 \\
8 & 55\end{array}$ & $\begin{array}{l}3 \mathbf{b} \\
3 \mathbf{b} \\
3 \mathbf{b}\end{array}$ & $\begin{array}{l}\text { None } \\
\text { None } \\
\text { Congenital } \\
\text { midline } \\
\text { nasal and } \\
\text { lip pit }\end{array}$ & $\begin{array}{l}2 \\
1 \\
1\end{array}$ & $\begin{array}{l}0 \\
2 \\
1 \text { (Still- } \\
\text { born, } \\
\text { VSD) }\end{array}$ \\
\hline & $\begin{array}{l}67 \\
72\end{array}$ & $\begin{array}{l}\mathbf{H} \\
\mathbf{G}\end{array}$ & $\begin{array}{l}955 \\
956\end{array}$ & $\begin{array}{l}3 \mathrm{~b} \\
3 \mathrm{~b}\end{array}$ & $\begin{array}{l}\text { None } \\
\text { None } \\
\text { Total }\end{array}$ & $\begin{array}{c}0 \\
1 \\
14(A)\end{array}$ & $\begin{array}{r}1 \\
1 \\
14\end{array}$ \\
\hline
\end{tabular}

are also shown. Patient 49 was type $3 b$ without associated malformation.

\section{OTHER RELATIVES}

The 79 index patients had 130 sibs of whom one, a sister of the index patient 49 who had an affected son, was also affected. This sister had oesophageal atresia without tracheo-oesophageal fistula, duodenal atresia, anteriorly placed anus, and malrotation of the midgut (Dennis et al., 1973). In addition, 2 brothers had pyloric stenosis and one anencephaly, and one sister had a meningomyelocele and one anencephaly. The sibs are shown in Table 2 separately for the index patients with and without children.

One patient had a twin (on examination clearly monozygotic) who was unaffected.

The index patients had 30 nephews and nieces, none of whom had tracheo-oesophageal fistula. One sister's daughter of a male patient had pyloric stenosis and one sister's daughter of a female patient had hydrocephalus.

\section{MATERNAL AGE AND BIRTH ORDER}

The distribution of maternal age standardised for birth order and birth order standardised for maternal age for 76 of the 79 patients is shown in Table 3 compared with that for England and Wales. The 29 index patients born 1947 to 1954 are compared with those for England and Wales born in

Table 2 Sibs of those treated for tracheo-oesophageal fistula showing those also affected $(A)$

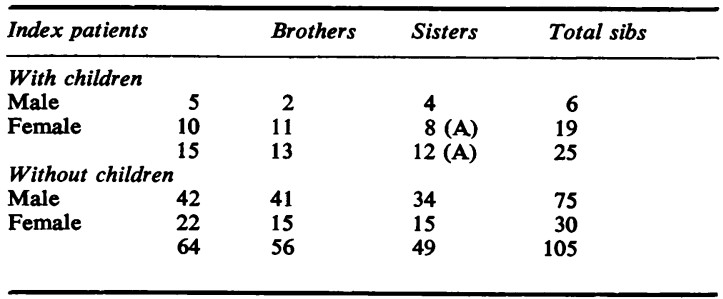

Table 3(a) Distribution by maternal age standardised for birth order

\begin{tabular}{llllll}
\hline & -24 & $25-29$ & $30-34$ & $40+$ & Total \\
\hline Observed & 24 & 26 & 18 & 8 & 76 \\
Expected & 25.78 & 24.81 & 15.47 & 9.94 & \\
& & & $0.9>P>0.8$ & \\
\hline
\end{tabular}

Fig. 3(b) Distribution by number of previous live born sibs standardised for maternal age

\begin{tabular}{lllccl}
\hline & 0 & 1 & 2 & $3+$ & Total \\
\hline Observed & 45 & 19 & 9 & 3 & 76 \\
Expected & 30.30 & 22.72 & $\begin{array}{c}11 \cdot 62 \\
\text { (1).005 }>\text { P }>0.001\end{array}$ & \\
\hline
\end{tabular}


1952, and the 47 index patients born 1955 to 1959 with those for England and Wales born in 1957 (Registrar General's Statistical Review Part II, Table HH).

\section{Discussion}

The finding of one affected child in $\mathbf{2 8}$ gives only a rough guide for counselling of patients on the risk to their children, because the series is as yet small. The true risk may well be less, since for most malformations the risk for children is close to the risk for sibs. The findings, however, exclude a high risk, such as would have been found in the unlikely event of type $3 \mathrm{~b}$ tracheo-oesophageal fistula being a dominant condition, with a high rate of manifestation, and almost all cases the result of fresh mutation.

The figure of one sib affected in 130 (including 4 stillbirths) is compatible with the Bristol series of David and O'Callaghan (1975), where 0 in 340 older sibs were affected (the information came from the medical records and not from direct questioning of the family). In addition, in their series, the parents of one boy with oesophageal atresia and rectal atresia later had two similarly affected children (the family reported by Forrester and Cohen, 1970); but this, they note, probably represents a distinct syndrome. The empirical recurrence risk for sibs is evidently low.

It is noteworthy that 3 of 130 sibs in the present study had central nervous system malformations (one with meningomyelocele and two with anencephaly). In the Bristol series, of the $\mathbf{3 4 0}$ older sibs and 25 younger, five had anencephaly, one spina bifida, and two hydrocephalus (aqueduct stenosis). The expected number of central nervous system malformations in the two series would be about 0.4 and $1 \cdot 5$, respectively.
No strong indication of environmental facto was found in this series. In contrast to the Bristo series, there was no effect of maternal age. Thefe was an excess of first born and a deficit of later bor at the 1 in 100 level of significance. The Brist series showed a similar trend, but one which was nof significant.

At present, a risk of about $1 \%$ is a reasonable figure to use in genetic counselling for children and sibs of index patients with type $3 \mathrm{~b}$ tracheo-oesephageal fistula, assuming that no other relatives of the index patient are affected.

\section{References}

Cudmore, R. E. (1978). Neonatal Surgery, ed P. P. Rickhari J. Lister, and I. M. Irving. Butterworths, London.

David, T. J., and O'Callaghan, S. E. (1975). Oesophageą atresia in the South West of England. Journal of Medicall Genetics, 12, 1-11.

Dennis, N. R., Nicholas, J. L., and Kovar, I. (1973). OesQ phageal atresia: 3 cases in 2 generations. Archives Disease in Childhood, 48, 980-982.

Engle, P. M. A., Vos, L. J. M., De Vris, J. A., and Kuijjeథ P. J. (1970). Esophageal atresia with tracheosophageal fistula in mother and child. Journal of Pediatric Surgerf 5, 564-565.

Forrester, R. M., and Cohen, S. J. (1970). Esophageal atresit associated with an anorectal anomaly and probabte laryngeal fissure in 3 siblings. Journal of Pediatric Surger 5, 674-675.

Gray, S. W., and Skandalakis, J. E. (1972). Embryology f Surgeons. Saunders, London.

Leck, I., Record, R. G., McKeown, T., and Edwards, J. Iף (1968). The incidence of malformations in Birminghan England 1950-59. Teratology, 1, 263-280.

Vogt, E. G. (1929). Congenital esophageal atresia. Americă Journal of Roentgenology, 22, 463-465.

Requests for reprints to Professor C. O. Carter MRC Clinical Genetics Unit, Institute of Chila Health, 30 Guilford Street, London WC1N 1EH. 